\title{
Model Pengembangan Kewirausahaan di Universitas Widya Kartika Surabaya
}

\author{
Muis Murtadho, Robby Kurniawan Budhi, Risma Andarini \\ Universitas Widya Kartika Surabaya \\ e-mail:muis@widyakartika.ac.id
}

\begin{abstract}
The large number of unemployed college graduates had become a big problem for the education world. Moreover, the imbalance that happened between the number of job vacancies and the work demands, made many university graduates work in the field which was not in accordance to the knowledge they had learned. In order to overcome these conditions, an entrepreneurial learning needed to be improved in the college. This improvement is hoped to create independent entrepreneurial students based on the acience and technology which later would be able to provide the job opportunities and develop the value of products and services. To achieve this situation, a model of entrepreneurial development which consisted of these three activities: the entrepreneurial education, the internship experience in the association companies, and the entrepreneurial practices was proven in increasing the students' success of students in starting a business based on science and technology.
\end{abstract}

Keywords: development, entrepreneurship, science-technology

\section{LATAR BELAKANG}

Angka pengangguran terdidik atau lulusan perguruan tinggi tahun 2017 tercatat sebesar 630.000 orang atau sekitar $8,85 \%$ dari jumlah pengangguran di Indonesia yang mencapai 7 juta jiwa. Banyaknya pengangguran terdidik menjadi problem pendidikan tinggi di Indonesia. Tahun 2017, perguruan tinggi di Indonesia meluluskan sebanyak 1.046.141 mahasiswa yang akan memasuki dunia kerja.

Banyaknya lulusan tersebut tak sebanding dengan jumlah angkatan kerja di Indonesia sehingga memicu naiknya supply tenaga kerja terdidik yang tidak sebanding dengan permintaan jumlah tenaga kerja di Indonesia. Hal tersebut mendorong terjadinya pengangguran terdidik serta banyaknya ketidaksesuaian antara tingkat pendidikan atau keilmuan dengan pekerjaan yang digelutinya serta pengupahan yang murah. Situasi seperti ini adalah suatu dampak dari sistem pendidikan yang banyak lebih memfokuskan mahasiswa untuk menjadi pekerja, pejabat yang dipandang mempunyai kedudukan atau status sosial di masyarakat.

Di negara maju misalnya Jerman, sudah terjalin link and match antara pendidikan tinggi dan industri. Negara tersebut menerapkan dual system pada kurikulum pendidikan yang berkualitas di mana sistem pembelajaran 30\% dilakukan di kampus dan 70\% dilakukan pemagangan dan praktik kerja di industri sehingga tak heran kompetensi SDM di negara tersebut 75\% berasal dari industri atau swasta sedangkan $15 \%$ berasal dari pemerintah.

Berbeda halnya dengan kampus yang mempunyai tujuan pendidikan entrepreneur yang menitikberatkan mahasiswa diciptakan untuk berusaha atau mencetak pekerjaan. Mahasiswa diajarkan untuk mandiri serta mengambil peluang dari meningkatkan kebutuhan masyarakat atas barang dan jasa menjadi kesempatan bisnis yang menguntungkan. Untuk menciptakan seorang pebisnis harus dimulai dari bangku kuliah, mengingat masa kuliah merupakan masa untuk meng- 
aktualisasikan kemampuan mahasiswa atas ilmu dan bakat yang ada di dalamnya.

Masa kuliah merupakan salah satu momen dalam pencarian jati diri mahasiswa sehingga harus dituntut untuk kreatif dalam memecahkan masalah ekonomi dan mampu untuk menciptakan ide atau produk baru yang mempunyai keunggulan dan dapat mempunyai nilai tambah bagi mahasiswa maupun masyarakat sekitar. Untuk menciptakan ide-ide mahasiswa yang kreatif maka lembaga pendidikan harus mampu memfasilitasi mahasiswa mengekspresikan bakat dan minat dalam menciptakan peluang menjadi sesuatu yang bermanfaat baik segi ekonomi maupun keilmuan.

Pendidikan entrepreneurship sangat penting di dunia kampus di mana entrepreneurship mampu mengubah sikap mahasiswa menjadi mandiri serta berani mengambil risiko seta mampu untuk membuat terobosan atau rekayasa ilmiah yang dapat bermanfaat bagi masyarakat secara ekonomi. Pendidikan entrepreneurship dapat dilakukan dengan pola pendidikan formal maupun non-formal berupa kegiatan magang usaha di perusahaan atau jasa sehingga mahasiswa dapat belajar nyata secara langsung di dunia bisnis serta pelaksanaan praktik wirausaha melalui pameran atau pemasaran untuk dapat melakukan riset pasar sebagai inspirasi untuk menciptakan peluang pasar.

Universitas Widya Kartika Surabaya merupakan kampus entrepreneurship yang berkomitmen untuk menciptakan entrepreneurship muda yang berwawasan iptek, di mana sistem pembelajaran yang digunakan yaitu lebih memfokuskan pada pendidikan dan keterampilan berbisnis dan menciptakan produk unggulan yang dapat dijual ke pasar. Iptek bagi kewirausahaan salah satu inkubasi bisnis di yang dikembangkan yaitu dengan konsep atau model pengembangan kewi- rausahaan melalui tiga strategi yaitu pendidikan kewirausahaan, magang kerja dan pameran. Dengan tiga strategi tersebut diharapkan pengetahuan mahasiswa wirausaha serta dapat mengambil peluang untuk menjadi kesempatan bisnis yang menguntungkan dapat dibaca dan diambil oleh mahasiswa sedangkan magang diperlukan untuk mempelajari secara langsung pengelolaan usaha serta memberikan inspirasi bisnis. Pameran merupakan suatu media untuk mengimplementasikan ilmu entrepreneurship yang telah diajarkan. Pameran memberikan pengetahuan mahasiswa untuk bisa mengekspresikan serta menjual produk yang dihasilkan dan memperkenalkan strategi bisnis yang dirintis untuk menjadi produk yang unggul dan bersaing di pasar bebas.

Suharti dan Sirine (2011) menemukan fakta bahwa dukungan akademik atau keikutsertaan mahasiswa dalam pelatihan dapat mendorong mahasiswa untuk menjadi pengusaha. Riset yang sama temukan oleh Rahmania dan Efendi (2014) yang meneliti pengetahuan mahasiswa dan praktik kerja terhadap kemauan untuk berwirausaha, menemukan bukti pengetahuan mahasiswa mampu menciptakan kemauan nyata untuk berwirausaha dan kegiatan praktik kerja berdampak nyata membentuk mahasiswa wirausaha. Sedangkan Johana Rumawow dalam publikasinya menyatakan praktik wirausaha dapat meningkatkan ekonomi mahasiswa. Sedangkan Shane (2004) dalam Sudarsih, pendidikan tinggi merupakan tempat sumber pengembangan teknologi yang sangat bermanfaat untuk menciptakan mahasiswa wirausaha. Murtini (2011) pendidikan kewirausahaan berpengaruh nyata dalam meningkatkan kecenderungan mahasiswa untuk menjadi pengusaha.

Kusuma Arum dan Indriayu (2017) yang meneliti magang mahasiswa di fakultas ekonomi 
UNS menyatakan pengalaman mahasiswa magang mampu memengaruhi mahasiswa berniat melakukan wirausaha. Magang dapat membentuk cara berpikir dan mengubah sikap dalam membentuk wirausaha. Riset yang dilakukan Backes dan Moog (2008) dalam Kusuma Arum (2017), magang dapat menciptakan pengalaman berwirausaha siswa. Siswoyo (2009) menyatakan bahwa pendidikan wirausaha sangat penting untuk memotivasi mahasiswa menjadi pengusaha, dan alumni program co-op atau magang mahasiswa terbukti lebih kompetitif di dunia kerja.

\section{METODE PENELITIAN}

Metode penelitian ini merupakan penelitian kausalitas yang mencari hubungan antar-variabel yang digunakan yaitu pendidikan kewirausahaan, magang kerja dan pameran terhadap kinerja wirausaha mahasiswa sehingga dapat diketahui hubungan antar-variabel tersebut.

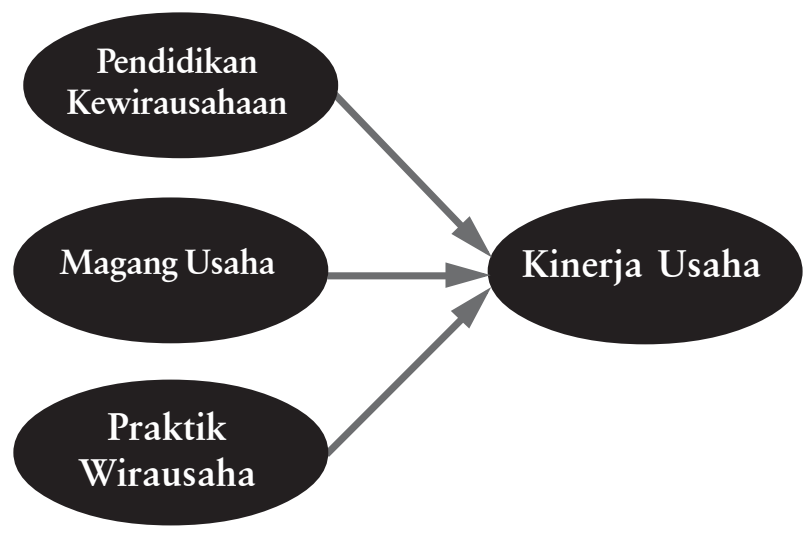

Gambar 1.1

Model Pengembangan Kewirausahaan

\section{Definisi Operasional Variabel}

Penelitian ini melakukan kajian strategi pengembangan mahasiswa kewirausahaan dengan tiga metode yang telah diberikan dapat digambarkan dalam variabel penelitian sebagai berikut.

\section{Variabel bebas (X)}

1. Pendidikan kewirausahaan $\left(\mathrm{X}_{1}\right)$ pendidikan dan pelatihan wirausaha yang diberikan kepada peserta program mahasiswa wirausaha yang meliputi motivasi berusaha, strategi pemasaran, pembuatan produk, mengelola modal, dan merek dagang serta marketing on line.

2. Magang kerja $\left(\mathrm{X}_{2}\right)$ adalah suatu kegiatan latihan kerja di tempat usaha yang sudah sukses, di mana mahasiswa dilatih untuk magang kerja sesuai dengan jenis usaha maupun jasa yang dirintisnya.

3. Praktik wirausaha $\left(\mathrm{X}_{3}\right)$ suatu kegiatan praktik wirausaha dengan membuat produk atau menjual produk yang dihasilkan.

\section{Variabel terikatnya (Y)}

Kinerja usaha: hasil usaha yang dicerminkan dari kualitas usaha maupun banyaknya omset penjualan serta penggunaan teknologi praktik bisnis.

\section{METODE PENGUMPULAN DATA}

Penelitian ini dilakukan pada mahasiswa peserta Program Pengembangan Kewirausahaan (PPK) di Universitas Widya Kartika Tahun 2018 sebanyak 31 mahasiswa wirausaha yang semua digunakan sebagai objek penelitian atau sensus. Metode pengumpulan data dilakukan dengan kuesioner untuk mengukur efektivitas model pengembangan kewirausahaan yang meliputi pelatihan kewirausahaan, magang kerja dan pameran yang telah diberikan selama 8 bulan serta untuk menggali informasi lebih mendalam faktor yang mendukung dan menghambat kegiatan pengembangan kewirausahaan dilakukan juga focus group discussion. 


\section{METODE ANALSISIS DATA}

Untuk mengetahui keberhasilan dari model pengembangan mahasiswa kewirausahaan di Universitas Widya Kartika Surabaya yang terdiri dari pelatihan kewirausahaan, magang kerja di tempat usaha serta pameran maka digunakan statistik regresi linier berganda, adapun persamaannya adalah sebagai berikut.

Di mana

$$
\mathrm{Y}=\mathrm{a}=\mathrm{b} 1 \mathrm{x}_{1}+\mathrm{b}_{2} \mathrm{x}_{2}+\mathrm{b}_{3} \mathrm{x}_{3}
$$

$\mathrm{Y}=$ Kinerja Usaha

$\mathrm{X}_{1}=$ Pendidikan Kewirausahaan

$\mathrm{X}_{2}=$ Magang Kerja

$\mathrm{X}_{3}=$ Praktek Kewirausahaan

$\mathrm{b}=$ Koefisien Regresi

\section{HASIL DAN PEMBAHASAN}

Penelitian ini dilakukan pada mahasiswa peserta Program Pengembangan Kewirausahaan (PPK) di Universitas Widya Kartika Surabaya sebanyak 31 mahasiswa. Model pengembangan kewirausahaan dilakukan dengan menggunakan tiga pendekatan yaitu pendidikan dan pelatihan bisnis berupa pelatihan kewirausahaan, motivasi berusaha, pembuatan produk, pengelolaan modal usaha dan pemasaran produk. Sedangkan yang kedua model pengembangan kewirausahaan dilakukan dengan cara magang wirausaha pada pengusaha yang sudah sukses, sedangkan yang ketiga dilakukan dengan metode praktik wirausaha yang meliputi praktik pembuatan produk, pemasaran, dan pameran. Untuk mengukur efektivitas keberhasilan model pengembangan kewirausahaan yang telah dilaksanakan maka diuji dengan menggunakan statistik dengan persamaan sebagai berikut.

$$
\mathrm{Y}=0.316+0.018+0,713+0,214
$$

Dari hasil pengujian statistik persamaan sebagaimana dalam tabel berikut.

Tabel 1 Hasil Output SPSS

\begin{tabular}{|c|c|c|c|}
\hline $\mathbf{R}$ & $\begin{array}{c}\mathbf{R} \\
\text { Square }\end{array}$ & $\begin{array}{c}\text { Ajusted } \\
\text { R Square }\end{array}$ & Sig \\
\hline 0,856 & 0,733 & 0,703 & 0,000 \\
\hline
\end{tabular}

Tabel di atas menunjukkan program PPK yang terdiri dari pelatihan, magang dan praktik wirausaha mempunyai kontribusi positif terhadap keberhasilan wirausaha mahasiswa sebesar 0,733 atau 73,35 dan sisanya 26,7 dipengaruhi faktor lain.

Melihat kenyataan ini bahwa model pengembangan kewirausahaan di Uwika harus dijalankan secara simultan sehingga berdampak signifikan pada keberhasilan mahasiswa dalam merintis usaha.

Tabel 2 Uji Korelasi Parsial

\begin{tabular}{|l|c|c|c|c|c|}
\hline \multirow{3}{*}{ Variabel } & $\begin{array}{c}\text { Unsetandarized } \\
\text { Coefficients }\end{array}$ & & $\begin{array}{c}\text { Stand } \\
\text { Coefficient }\end{array}$ & \multirow{2}{*}{$\mathbf{t}$} & Sig \\
\cline { 2 - 4 } & $\mathbf{B}$ & $\begin{array}{c}\text { Std. } \\
\text { Error }\end{array}$ & Beta & & \\
\hline Costant & .316 & .597 & & .528 & .602 \\
\hline Pendidikan & .018 & .096 & .019 & .186 & .854 \\
\hline Magang & .713 & .095 & .772 & 7,467 & .000 \\
\hline Praktik & .214 & .103 & .220 & 2,082 & .047 \\
\hline
\end{tabular}

Pelatihan wirausaha berpengaruh 0,019 dan tidak signifikan terhadap keberhasilan wirausaha mahasiswa atau sig $>0,05$ menunjukkan bahwa pendidikan pelatihan kewirausahaan mempunyai konstruksi yang kecil terhadap keberhasilan mahasiswa dalam berwirausaha. Keadaan ini terjadi karena pelatihan bisnis secara teori yang meliputi teori kewirausahaan, badan hukum usaha, desain produk dan sebagainya memberikan dampak kecil terhadap kemampuan mahasiswa untuk menerapkan berbagai strategi bisnis yang dijalankan. Hasil penelitian ini mendukung penelitian Siswoyo (2009), Murtini (2011), Suharti dan 
Sirine (2011) menyatakan pendidikan wirausaha sangat penting untuk meningkatkan jiwa kewirausahaan.

Magang mahasiswa adalah belajar secara nyata langsung di tempat mitra selama dua bulan, penempatan magang dilihat berdasarkan jenis usaha yang dirintis mahasiswa yaitu di rumah makan atau restoran, konveksi, pertokoan, dan usaha jasa dari pengujian statistik magang wirausaha berpengaruh 0,772 dan berdampak signifikan terhadap wirausaha mahasiswa atau sig $<0,05$ hal ini disebabkan karena pelaksanaan magang di tempat usaha dapat memberikan pengalaman nyata menjalankan usaha sesuai dengan bisnis yang digelutinya serta melihat secara langsung proses bisnis di tempat mitra dan dapat memberikan motivasi yang kuat dalam mengelola bisnis. Magang dipandang sangat tepat untuk menumbuhkan keterampilan mahasiswa dalam mengelola usaha yang meliputi penataan barang dagangan, merchandising, melayani pelanggan serta dapat membuat strategi pemasaran seperti halnya penetapan harga maupun kualitas produk. Dokumentasi pemberkasan, mengelola persediaan, mengolah bahan baku dan produksi, dan menangani komplain. Hasil penelitian ini mendukung temuan Siswoyo (2009) mahasiswa magang usaha lebih kompetitif di dunia kerja.

Praktik wirausaha berpengaruh 0,220 dan berdampak signifikan terhadap wirausaha mahasiswa sig $<0,05$. Praktik wirausaha yang meliputi pembuatan produk atau jasa, praktik berjualan dan pameran yang dilaksanakan dapat mengetahui kemampuan mahasiswa untuk mewujudkan pemikiran atau ide bisnisnya menjadi sebuah produk atau proses bisnis yang dapat dijual dan bernilai ekonomi tinggi. Praktik kewirausahaan ini juga meliputi kegiatan pemasaran produk baik pameran maupun dilakukan secara daring di media sosial. Model pengembangan kewirausahaan ini mendukung penelitian yang dilakukan oleh Rahmania dan Efendi (2014) praktik wirausaha menciptakan kemauan nyata untuk berusaha.

\section{SIMPULAN DAN DARAN}

\section{Simpulan}

1. Model pengembangan kewirausahaan di Universitas Widyakartika dengan menggunakan tiga pendekatan yaitu pendidikan kewirausahaan, magang kewirausahaan di industri mitra dan praktik wirausaha terbukti dapat meningkatkan kinerja wirausaha mahasiswa karena memiliki nilai sig $<0,05$.

2. Dari ketiga model pengembangan wirausaha mahasiswa yang meliputi pendidikan wirausaha, magang usaha di tempat mitra dan praktik wirausaha menyatakan bahwa variabel magang usaha di tempat mitra mempunyai kontribusi terhadap keberhasilan wirausaha peserta program PPK di Universitas Widya Kartika.

\section{Saran}

1. Model pengembangan kewirausahaan yang terdiri dari pendidikan wirausaha, magang di tempat usaha dan praktik kewirausahaan merupakan model yang tepat dapat meningkatkan kinerja wirausaha mahasiswa, untuk itu bagai pihak yang berkompeten, ristek dikti dan penyelenggara perguruan tinggi dapat menjadi pedoman dalam meningkatkan kinerja wirausaha mahasiswa.

2. Magang kerja usaha sangat berkontribusi terhadap keberhasilan wirausaha mahasiswa, untuk itu perlu peningkatan jumlah jam 
magang usaha mahasiswa sehingga kinerja wirausaha mahasiswa dapat meningkat.

\section{DAFTAR PUSTAKA}

Arum, A.E.K. \& Indriayu, M. 2017. Pengaruh Pengalaman Magang terhadap Niat Berwirausaha Mahasiswa (Studi pada Magang Mahasiswa Program Studi Pendidikan Ekonomi di Mini Market Tania FKIP UNS). Jurnal Pendidikan Bisnis dan Ekonomi, 2(2).

Hermawan, Sigit \& Sigit. 2016. Metode Penelitian Bisnis. Malang: MNC Publishing.

Murtini, W. 2012. Pendidikan Kewirausahaan dengan Pemodelan Wirausaha. Jurnal Ilmu Pendidikan, 17(5).

Rahmania, M., \& Effendi, Z.M. 2014. Pengaruh Pengetahuan Kewirausahaan, Praktik Kerja Industri dan Motivasi Berprestasi Terhadap Minat Berwirausaha Siswa Kelas XII Kom- petensi Keahlian Pemasaran SMK Negeri Bisnis dan Manajemen Kota Padang. Jurnal Kajian Pendidikan Ekonomi, 1(2).

Shane, S.A. 2004. Academic Entrepreneurship: University Spinoffs and Wealth Creation. Edward Elgar Publishing.

Siswoyo, B.B. 2009. Pengembangan Jiwa Kewirausahaan di Kalangan Dosen dan Mahasiswa. Jurnal Ekonomi Bisnis, 14(2), 35-45. Suharti, L. \& Sirine, H. 2012. Faktor-Faktor yang Berpengaruh terhadap Niat Kewirausahaan (Entrepreneurial Intention). Jurnal Manajemen dan Kewirausahaan, 13(2), 124-134. www.tribunnews.com/nasional/2017/11/08/ pengangguran-di-indonesia-tinggi-karenalulusan-perguruan-tinggi-terlalu-milihpekerjaan.

www.pikiran-rakyat.com/pendidikan/2018/03/26/ 630000-orang-sarjana-masih-menganggur421873. 